\title{
Efektivitas Model Pembelajaran Berbasis Masalah Terhadap Kemampuan \\ Menulis Teks Prosedur Kompleks Siswa Kelas X SMK Negeri 13 Medan \\ Tahun Pembelajaran 2013/2014
}

\section{Monalisa Frince S}

\begin{abstract}
ABSTRAK
Penelitian ini bertujuan untuk menunjukkan efektivitas model pembelajaran berbasis masalah terhadap kemampuan menulis teks prosedur kompleks siswa kelas X SMK Negeri 13 Medan Tahun Pembelajaran 2013/2014. Populasi penelitian ini adalah seluruh siswa kelas X SMK Negeri 13 Medan sebanyak 361 orang.Sampel diambil secara acak sebanyak 72 orang, 36 orang untuk kelas eksperimen (menggunakan model pembelajaran berbasis masalah) dan 36 orang untuk kelas kontrol (model pembelajaran ekspositori).Metode yang digunakan dalam penelitian ini adalah metode eksperimen.Instrumen yang digunakan adalah tes menulis teks prosedur kompleks dalam bentuk penugasan. Nilai rata-rata kelas eksperimen adalah 80,28 sedangkan untuk kelas kontrol adalah 70,14. Dengan demikian, dapat dikatakan bahwa nilai rata-rata kemampuan menulis teks prosedur kompleks lebih tinggi daripada kelas kontrol. Ini terbukti dari hasil uji " $\mathrm{t}$ " diperoleh $t_{\text {hitung }}>t_{\text {tabel }}$ yaitu 6,14>2,00. Dengan demikian dapat disimpulkan bahwa model pembelajaran berbasis masalah lebih efektif terhadap kemampuan menulis teks prosedur kompleks daripada model pembelajaran ekspositori.
\end{abstract}

Kata Kunci: efektivitas, Model Pembelajaran Berbasis Masalah, menulis teks prosedur kompleks.

\section{PENDAHULUAN}

Pendidikan merupakan sebuah aset masa depan yang menunjukkan berkembangnya suatu bangsa. Perkembangan tersebut ditandai dengan kesiapan untuk menjawab perubahan-perubahan yang terjadi. Perubahan-perubahan tersebut antara lain kemajuan teknologi informasi, ekonomi berbasis pengetahuan dan kebangkitan industri kreatif dan budaya. Hal ini menuntut SDM yang 
berkualitas, memiliki karakter, kompetensi yang menjual, memiliki kecakapan berkomunikasi, mempunyai pemikiran yang kritis dan memiliki pandangan positif terhadap hidup.

Kurikulum 2013 sebagai sarana untuk meningkatkan mutu pendidikan yang lebih baik dengan menghasilkan insan-insan kreatif, produktif, dan berkarakter.Oleh sebab itu Kurikulum 2013 dilaksanakan berdasarkan standar kompetensi lulusan, kompetensi dasar dan kompetensi inti.Sebagaimana Mulyasa (2013:63) menyatakan, perumusan tersebut terdiri atas empat hal.Hal pertama, standar kompetensi lulusan diturunkan dari kebutuhan.Kedua, standar isi diturunkan dari standar kompetensi lulusan.Ketiga, semua mata pelajaran berkontribusi terhadap pembentukan sikap, keterampilan dan pengetahuan.Hal keempat, mata pelajaran diturunkan dari kompetensi yang ingin dicapai.Hal terakhir, semua mata pelajaran diikat oleh kompetensi inti.

Kelima hal di atas ditujukan sebagai jawaban atas kebutuhan-kebutuhan masyarakat untuk menghadapi tantangan saat sekarang atau yang akan datang. Perumusan kurikulum diturunkan dari kebutuhan-kebutuhan masyarakat untuk menghadapi tantangan masa depan. Sebagaimana yang dikemukan Prastowo (2013: 64),

Kurikulum harus membekali peserta didik dengan berbagai kompetensi. Kompetensi tersebut antara lain: kemampuan berkomunikasi, kemampuan berpikir jernih dan kritis, kemampuan mempertimbangkan segi moral suatu permasalahan, kemampuan menjadi warga Negara yang bertanggungjawab, kemampuan mencoba untuk mengerti dan toleran terhadap pandangan yang berbeda, kemampuan hidup dalam masyarakat yang mengglobal, memiliki minat luas dalam kehidupan, memiliki kesiapan untuk bekerja, memiliki kecerdasan sesuai dengan bakat/minatnya dan memiliki rasa tanggung jawab terhadap lingkungan.

Dalam kurikulum 2013 pembelajaran bahasa Indonesia mengalami perubahan secara total. Dalam implementasinya, pembelajaran bahasa Indonesia 
menggunakan pendekatan berbasis teks. Hal ini bertujuan agar siswa dapat mengembangkan kemampuan menalar dalam bentuk lisan dan tulisan. Menurut Kemdikbud (2013:42), persentase kegiatan siswa 10\% mendengarkan, 23\% berbicara, tata bahasa $6 \%$, membaca $30 \%$ dan menulis $31 \%$." Pendekatan berbasis teks lebih menguatkan siswa pada kegiatan menulis. Dalam pembelajaran bahasa Indonesia X SMK terdapat lima kegiatan menulis yaitu, menulis teks anekdot, menulis teks eksposisi, menulis teks laporan observasi, menulis teks negosiasi dan menulis teks prosedur kompleks.

Kegiatan menulis memiliki hubungan yang erat dengan berpikir.Menulis bukan hanya sekedar kegiatan berbahasa, namun juga dapat digunakan sebagai wadah menuangkan hasil pemikiran. Semakin banyak menulis maka siswa akan terlatih untuk berpikir kritis, mempunyai daya nalar yang tinggi dan aktif dalam mengembangkan prestasi akademik.

Namun kenyataan di lapangan tidak sesuai dengan yang diharapkan dikarenakan hasil belajar siswa dalam kegiatan menulis tergolong rendah.Pengakuan dari siswa sendiri pembelajaran menulis merupakan kegiatan yang membosankan.Ketika diberi tugas untuk menulis siswa sengaja mengulur waktu agar tugas menulis tersebut menjadi tugas rumah.Hal ini diperbuat agar tugas menulis tersebut dapat disalin secara utuh dari internet atau media cetak bukan hasil pikiran siswa itu sendiri.Dengan demikian dapat disimpulkan indikator pencapaian kompetensi siswa mampu menulis tidak tercapai.Penelitian Purba mengatakan, "Kemampuan siswa dalam menulis rendah hal tersebut disebabkan karena siswa hanya diajarkan untuk terampil menguasai teori menulis daripada terampil dalam menerapkannya." Pembelajaran menulis akan membosankan bila siswa hanya diajarkan secara teori tanpa mempraktekkan secara langsung.

Wujud dari pembelajaran menulis terlihat pada pembelajaran bahasa Indonesia menulis teks yaitu pembelajaran teks prosedur kompleks yang dimuat dalam Kurikulum 2013 di kelas X SMK. Dengan KD "Memproduksi teks prosedur kompleksyang koheren sesuai dengan karakteristik teks yang akan dibuat baik secara lisan maupun tulisan.” Teks prosedur kompleks merupakan teks yang berisikan 
tujuan dan langkah-langkah dalam mencapai tujuan tertentu.Contohnya ketika seseorang hendak mengurus kartu pelajar maka harus mengikuti prosedur yang berlaku.Kompleksnya sebuah prosedur dikarenakan langkah-langkah harus dilakukan dengan rinci tanpa melangkahi tahapan-tahapan yang telah ditetapkan.

Menulis tidak dapat tercipta tanpa motivasi atau rangsangan dari guru agar siswa mau menulis. Motivasi dapat berupa pemberian semangat untuk siswa mau menulis dan memperhatikan dengan baik pembelajaran yang akan dilaksanakan. Rangsangan dapat dilaksanakan dengan pemilihan model yang tepat terhadap kegiatan menulis.Model pembelajaran di desain untuk mengatur jalannya pembelajaran dari awal sampai akhir pembelajaran. Hal ini didukung oleh Istarani (2012:1) menyatakan, "Model pembelajaran adalah seluruh rangkaian penyajian materi ajar yang meliputi segala aspek sebelum, sedang dan sesudah pembelajaran yang dilakukan guru serta segala fasilitas yang terkait yang digunakan secara langsung atau tidak langsung dalam proses belajar mengajar.”

Penulis memperkenalkan Model Pembelajaran Berbasis Masalah terhadap kemampuan menulis teks prosedur kompleks.Model pembelajaran ini bukanlah model pembelajaran yang baru dalam dunia pendidikan hanya saja model pembelajaran ini memiliki satu keunggulan untuk menarik perhatian siswa dalam kegiatan menulis yaitu merangsang siswa untuk aktif dalam belajar karena siswa ditantang untuk memecahkan masalah yang diberikan guru.Model Pembelajaran Berbasis Masalah merupakan model pembelajaran yang menggunakan masalah yang nyata, prosesuntuk siswa belajar, baik ingatan maupun keterampilan berpikir kritis.Dengan demikian siswa didorong untuk lebih aktif terlibat dalam materi pelajaran dan mengembangkan keterampilan berpikir kritis.Pembelajaran berdasarkan masalah kegunaannya adalah untuk merangsang siswa berpikir kritis dalam situasi yang berorientasi masalah. Masalah-masalah yang diberikan guru merupakan masalah yang terdapat dalam kehidupan nyata sehingga siswa dapat menghubungkannya dengan pengalaman yang pernah dialami langsung ataupun yang didengar dari orang lain. 
Ibrahim dan Nur (dalam Rusman 2013:241) mengemukakan,"PBM merupakan salah satu pendekatan pembelajaran yang digunakan untuk merangsang berpikir tingkat tinggi siswa dalam situasi yang berorientasi pada masalah dunia nyata, termasuk didalamnya belajar bagaimana belajar."Fokus pembelajaran berbasis masalah ini ada pada masalah yang dipilih sehingga siswa tidak hanya mempelajari konsep-konsep yang berhubungan dengan masalah tetapi juga mencari cara untuk memcahkan masalah secara ilmiah. Pembelajaran yang dimulai dengan suatu masalah, apalagi bila masalah tersebut bersifat kontekstual maka keadaan seperti ini akan mendorong rasa ingin tahu siswa dan memunculkan banyak pertanyaan. Dan pada kondisi seperti inilah guru sebagai fasilitator berperan untuk mengarahkan siswa menemukan konsep-konsep memecahkan masalah tersebut. Pembelajaran berbasis masalah ini akan mendorong siswa untuk berinisiatif belajar.Siswa yang belajar memecahkan suatu masalah maka mereka akan menerapkan pengetahuan yang dimilikinya atau berusaha mengetahui pengetahuan yang diperlukan. Apa yang dilakukan siswa sesuai dengan keadaan nyata bukan lagi teoretis sehingga masalah-masalah tersebut akan meningkatkan berpikir kritis siswa.

Sedangkan Model Pembelajaran Ekspositori Menurut Sanjaya (2010:177), "Model Ekspositori adalah metode pembelajaran yang menekankan kepada proses penyampaian materi secara verbal dari seorang guru kepada sekelompok siswa dengan maksud agar siswa dapat menguasai materi secara optimal." Dalam model pembelajaran ini guru menyampaikan materi secara verbal sementara siswa menyimak data-data tersebut dan mengingatnya. Tidak ada tuntutan untuk siswa berpikir selama materi disampaikan sehingga siswa tidak memahami materi yang disampaikan oleh guru.Pembelajaran menulis teks prosedur kompleks tidak dapat dilakukan hanya dengan penyampaian materi secara verbal.Struktur dan ciri kebahasaan yang dimiliki prosedur kompleks harus dipahami siswa lewat praktek langsung dan yang terpenting rangsangan yang diberikan guru agar siswa mau belajar. 


\section{METODOLOGI PENELITIAN}

Metode penelitian merupakan hal yang penting dalam pelaksanaan penelitian. Adapun metode yang digunakan dalam penelitian ini adalah metode eksperimen dengan desain post-test control only desain group. Metode ini dipergunakan karena peneliti ingin menggambarkan hasil belajar siswa menggunakan model pembelajaran berbasis masalah dengan model pembelajaran ekspositori terhadap kemampuan menulis teks prosedur kompleks siswa kelas $\mathrm{X}$ SMKNegeri 13 Medan tahun pembelajaran 2013/2014.

\section{PEMBAHASAN PENELITIAN}

Data yang diperoleh dari penelitian ini adalah data Kemampuan Menulis Teks Prosedur Kompleks menggunakan Model Pembelajaran Berbasis Masalah pada Siswa Kelas X SMK Negeri 13 Medan Tahun Pembelajaran 2013/2014.Jumlah sampel dalam penelitian ini sebanyak 36 siswa.Oleh karena itu, data kemampuan menulis teks prosedur kompleks meningkat menggunakan Model Pembelajaran Berbasis Masalah. Data yang diperoleh nilai rata-rata pada kelas eksperimen adalah 80,28 dan termasuk dalam kategori baik dengan skor tertinggi 95 dan skor terendah 65. Dengan rincian, skor 95 diperoleh 2 orang siswa, skor 90 diperoleh 5 orang siswa, skor 85 diperoleh 7 orang siswa, skor 80 diperoleh 9 orang siswa, skor 75 diperoleh 7 orang siswa, skor 70 diperoleh 4 orang siswa dan skor terendah 65 diperoleh 2 orang siswa. Sedangkan nilai ratarata pada kelas kontrol adalah 70,14 dan termasuk dalam kategori cukup dengan skor tertinggi 85 dan skor terendah 55. Dengan rincian, skor 85 diperoleh 4 orang siswa, skor 80 diperoleh 2 orang siswa, skor 75 diperoleh 8 orang siswa, skor 70 diperoleh 10 orang siswa, skor 65 diperoleh 5 orang siswa, skor 60 diperoleh 3 orang siswa dan skor terendah 555 diperoleh 4 orang siswa. Kemampuan siswa menulis teks prosedur kompleks menggunakan Model Pembelajaran Berbasis Masalah termasuk dalam tiga kategori yaitu, sebanyak 14 siswa (39\%) dalam kategori sangat baik, 16 siswa (44\%) dalam kategori baik dan sebanyak 6 siswa (17\%) dalam kategori cukup. Sedangkan kemampuan siswa menulis teks prosedur 
kompleks menggunakan Model Pembelajaran Ekspositori termasuk dalam empat kategori yaitu, sebanyak 4 siswa (11\%) dalam kategori sangat baik, 10 siswa (28\%) dalam kategori baik, 15 siswa (42\%) dalam kategori cukup dan sebanyak 7 siswa (19\%) dalam kategori kurang.

Berdasarkan aspek penilaian kemampuan menulis teks prosedur kompleks, hasil belajar siswa kelas eksperimen termasuk dalam kategori baik karena berada pada nilai rata-rata 80,28 dan mencapai KKM (Kriteria Ketuntasan Minimal) dengan nilai 75. Frekuensi penilaian jumlah siswa lebih banyak masuk ke dalam kategori baik sebesar 44\%.Aspek penilaian tersebut diuraikan sesuai dengan indikator penilaian menulis teks prosedur kompleks. Pertama, struktur teks prosedur kompleks, siswa yang mencapai skor tertentu pada masing-masing predikator dari 36 siswa terdapat 36 siswa (100\%) mendapatkan skor 20 artinya keseluruhan siswa mendapatkan skor 20 sebagai skor tertinggi karena memiliki tujuan dan langkah-langkah seperti yang terdapat pada struktur teks prosedur kompleks. Kedua, ciri kebahasaan teks prosedur kompleks. Sebanyak 22 siswa (61\%) mendapatkan skor tertinggi 30 karena lengkap menuliskan empat ciri kebahasaan, 1 siswa (3\%) mendapatkan skor 25 karena dapat menuliskan tiga ciri kebahasaan, 11 siswa (31\%) mendapatkan skor 20 karena dapat menuliskan dua ciri kebahasaan teks prosedur kompleks dan 2 siswa (6\%) dengan satu ciri kebahasaan teks prosedur kompleks. Ketiga, EYD (Ejaan Yang Disempurnakan). Sebanyak 9 siswa (25\%) dengan skor tertinggi 20 karena menggunakan tanda baca, huruf kapital dan kalimat yang efektif.Sebanyak 27 siswa (75\%) mendapatkan skor 15 karena kurang tepat menggunakan tanda baca, huruf kapital dan kalimat yang efektif. Keempat, Diksi yaitu sebanyak 8 siswa (22\%) mendapatkan skor 15 dan 28 siswa (78\%) mendapatkan skor 10. Kelima, Koherensi yaitu sebanyak 6 siswa (17\%) mendapatkan skor 15, 2 siswa (6\%) mendapatkan skor 10 dan 28 siswa (78\%) mendapatkan skor 5. Sedangkan pada kelas kontrol, hasil belajar siswa kelas kontrol termasuk dalam kategori cukup karena berada pada nilai rata-rata70,14 namun tidak mencapai KKM (Kriteria Ketuntasan Minimal) dengan nilai 75. Frekuensi penilaian jumlah siswa lebih 
banyak masuk ke dalam kategori cukup sebesar 42\%.Aspek penilaian tersebut diuraikan sesuai dengan indikator penilaian menulis teks prosedur kompleks. Pertama, struktur teks prosedur kompleks, siswa yang mencapai skor tertentu pada masing-masing predikator dari 36 siswa terdapat 33 siswa (92\%) mendapatkan skor 20 sebagai skor tertinggi karena memiliki tujuan dan langkah-langkah seperti yang terdapat pada struktur teks prosedur kompleks, 3 siswa (8\%) mendapatkan skor 10. Kedua, ciri kebahasaan teks prosedur kompleks. Sebanyak 3 siswa (8\%) mendapatkan skor tertinggi 30 karena lengkap menuliskan empat ciri kebahasaan, 3 siswa (8\%) mendapatkan skor 25 karena dapat menuliskan tiga ciri kebahasaan, 21 siswa (58\%) mendapatkan skor 20 karena dapat menuliskan dua ciri kebahasaan teks prosedur kompleks dan 6 siswa (17\%) dengan satu ciri kebahasaan teks prosedur kompleks. Ketiga, EYD (Ejaan Yang Disempurnakan). Sebanyak 8 siswa (22\%) dengan skor tertinggi 20 karena menggunakan tanda baca, huruf kapital dan kalimat yang efektif.Sebanyak 28 siswa (78\%) mendapatkan skor 15 karena kurang tepat menggunakan tanda baca, huruf kapital dan kalimat yang efektif. Keempat, Diksi yaitu sebanyak 1 siswa (3\%) mendapatkan skor 15 dan 35 siswa (97\%) mendapatkan skor 10. Kelima, Koherensi yaitu sebanyak 4 siswa (11\%) mendapatkan skor 10 dan 32 siswa (89\%) mendapatkan skor 5.

Dari perolehan nilai rata-rata yang ada pada kelas eksperimen dan kelas kontrol menunjukkan bahwa Model Pembelajaran Berbasis Masalah lebih efektif dalam meningkatkan kemampuan siswa menulis teks prosedur kompleks daripada Model Pembelajaran Ekspositori. Pada kelas eksperimen siswa yang mendapatkan kategori sangat baik pada indikator penilaian struktur teks sebanyak 36 siswa $(100 \%)$, indikator ciri kebahasaan teks sebanyak 22 siswa (61\%), indikator EYD sebanyak 9 siswa (25\%), indikator diksi sebanyak 8 (22\%) dan indicator koherensi sebanyak 6 siswa (17\%). Sedangkan pada kelas kontrol siswa yang mendapatkan kategori sangat baik pada indikator penilaian struktur teks sebanyak 33 siswa (92\%), indikator ciri kebahasaan teks sebanyak 3 siswa (8\%), indikator 
EYD sebanyak 8 siswa (22\%), indikator diksi sebanyak 1 (3\%) dan indicator koherensi sebanyak 0 siswa (0\%). Lebih jelasnya disajikan dalam tabel berikut:

TABEL II

TABEL PERSENTASE RATA-RATA KELAS EKSPERIMEN DAN KELAS KONTROL

\begin{tabular}{|l|c|c|c|c|}
\hline \multirow{2}{*}{ Indikator } & \multicolumn{4}{|c|}{ Persentase Rata-rata Perolehan Skor } \\
\cline { 2 - 5 } & $\begin{array}{c}\text { Model Pembelajaran } \\
\text { Berbasis Masalah }\end{array}$ & \multicolumn{2}{c|}{ Model Ekspositori } \\
\cline { 2 - 5 } & $\begin{array}{c}\text { Jumlah } \\
\text { Siswa }\end{array}$ & $\%$ & $\begin{array}{c}\text { Jumlah } \\
\text { Siswa }\end{array}$ & $\%$ \\
\hline Struktur Teks & 36 & $100 \%$ & 33 & $92 \%$ \\
\hline Ciri Kebahasaan Teks & 22 & $61 \%$ & 3 & $8 \%$ \\
\hline EYD & 9 & $25 \%$ & 8 & $22 \%$ \\
\hline Diksi & 8 & $22 \%$ & 1 & $3 \%$ \\
\hline Koherensi & 6 & $17 \%$ & 0 & $0 \%$ \\
\hline
\end{tabular}

Berdasarkan hasil analisis data yang dilakukan, kemampuan siswa dalam menulis teks prosedur kompleks menggunakan Model Pembelajaran Berbasis Masalah efektif untuk meningkatkan hasil belajar siswa.Hal ini karena Hal ini disebabkan karena Model Pembelajaran Berbasis Masalah menuntut siswa untuk aktif membangun kosep-konsepnya sendiri untuk dapat mengerti, memahami dan mengikuti pembelajaran.Masalah yang diberikan guru merangsang siswa aktif untuk mencari tahu baik secara individu maupun kelompok. Menyajikan karya berupa teks prosedur kompleks berdasarkan apa yang dipahami dan diketahui. Tugas guru merangsang siswa di awal pembelajaran dengan sebuah masalah yang berhubungan dengan pembelajaran teks prosedur kompleks setelah itu mengarahkan siswa untuk menyelesaikan masalah dan akhirnya menyajikan karya sebuah teks prosedur kompleks. 
Model Pembelajaran Ekspositori menjadikan siswa pasif selama pembelajaran dan tidak memahami pembelajaran. Penyajian materi secara lisan tidak merangsang siswa untuk tertarik pada pembelajaran.Siswa tidak berpikir terhadap materi yang disampaikan.Teks Prosedur Kompleks yang dibuat tidak sesuai dengan yang diharapkan.Model Pembelajaran Ekspositori tidak efektif digunakan pada pembelajaran teks prosedur kompleks karena kurang dapat merangsang siswa untuk aktif dalam pembelajaran

Berdasarkan uji analisis diperoleh uji normalitas kelas eksperimen $L_{\text {hitung }}<$ $L_{\text {tabel }}(0,1232<0,1476)$. Hal ini membuktikan bahwa data variabel $\mathrm{X}$ berdistribusi normal.Dan uji normalitas kelas kontrol $L_{\text {hitung }}<L_{\text {tabel }}(0,1211<0,1476)$. Hal ini membuktikan bahwa data variabel Y berdistribusi normal. Uji homogenitas yang dilakukan $X^{2}$ (Chi Kuadrat) hitung sebesar 0,80. Ternyata $X^{2}$ hitung $<X^{2}$ tabel yaitu $0,80<43,8$. Hal ini membuktikan bahwa varians populasi adalah homogen.Dan dengan $t_{0}$ ( $\mathrm{t}$ observasi) yang diperoleh lebih besar dari ttabel yaitu 6,14 > 2,00 maka hipotesis alternatif (Ha) diterima.Hal ini membuktikan bahwa Model Pembelajaran Berbasis Masalah membuat siswa mampu memahami pembelajaran, berpikir kritis menyelesaikan masalah karena siswa itu sendiri yang membangun konsep-konsep pembelajaran tersebut dan dihubungkan dengan pengetahuan dan pengalaman tiap-tiap siswa.

\section{PENUTUP}

Berdasarkan hasil penelitian yang telah diuraikan pada penjelasan sebelumnya maka dapat diambil kesimpulan bahwa pemerolehan nilai rata-rata kemampuan menulis teks prosedur kompleks menggunakan model pebelajaran berbasis masalah yaitu 80,28 dengan kategori baik. Sedangkan pemerolehan nilai rata-rata kemampuan menulis teks prosedur kompleks dengan menggunakan model pembelajaran ekspositori yaitu 70,14 dengan kategori cukup. Model 
Pembelajaran Berbasis Masalah lebih efektif digunakan untuk menulis teks prosedur kompleks. Hal itu terlihat dari tabel t pada taraf signifikan 5\% dengan $\mathrm{dk}=(\mathrm{N} 1+\mathrm{N} 2)-2=(36+36)-2=70$. Pada tabel $\mathrm{t}$ dengan dk 70 diperoleh taraf signifikan $5 \%=2,00$ Oleh karena itu $t_{0}$ yang diperoleh lebih besar dari t tabel yaitu 6,14> 2,00 maka hipotesis alternatif $(\mathrm{Ha})$ diterima.

\section{DAFTAR PUSTAKA}

Arikunto, Suharsimi. 2006. Prosedur Penelitian Suatu Pendekatan Praktis. Jakarta: Rineka Cipta.

Istarani. 2012. 58 Model Pembelajaran Inovatif. Medan: Media Persada Kemdikbud.2013a. Bahasa Indonesia: Ekspresi Diri dan Akademik Kelas X. Jakarta: Kemdikbud.

Mulyasa. 2013. Pengembangan dan Implementasi Kurikulum 2013. Bandung: PT Remaja Rosdakarya

Prastowo, Andi. 2013. Pengembangan Bahan Ajar Tematik. Yogyakarta: DIVA Press.

Rusman.2013. Model-model Pembelajaran Mengembangkan Profesionalisme

Guru. Jakarta: PT. Raja Grafindo Persada.

Sanjaya, Wina. 2010. Pembelajaran Aktif Diskusi. Jakarta: PT Rineka Cipta. 
